\title{
Orest Krasiwski
}

(Gniezno)

\section{Ivan Parubchak}

(Lwów)

\section{TRANSFORMATION OF POLITICAL CULTURE IN THE PROCESS OF SOCIAL DEMOCRATIZATION OF STATES DURING TRANSITIONAL PERIOD}

DOI 10.14746/SEG.2014.10.8

\begin{abstract}
The phenomenon of political culture has been considered as the basis for stability and dynamic development of thestate. Correlation between functioning of democratic institutions and transformation of political culture in the country has been studied. Forms have been investigated and stages of social democratization at the present time have been analyzed. The role of political and cultural factors in the evolutionary processes of social democratization has been substantiated.

\section{Key words}

evolutionary processes, social democratization, political culture, transformation, democratic institutions, cultural factors
\end{abstract}


Despite the fact that transformation process of non-democratic regimes into democratic ones occurs individually in different countries with its own problems and difficulties, advances and challenges, it has certain common features, allowing one to determine its character, identify the types and stages of transition. Serious discussions concerning democracy development are possible only after the society has achieved and institutionally consolidated the social political consensus. Decision of institutionalization of basic democratic procedures is the only available solution, occurring as a result of interaction of a wide range of political forces; therefore, it does not exclude, but is rather followed by tough political competition.

Conversion to democracy can be characterized by challenges and controversies. Generally, democratization process represents a gradual transition from one stage of development to the other, each having its own range of issues. This competition may acquire a severe form, accompanied by political polarization, but without abandoning national unity. Thus, maintaining national unity is regarded to be an issue of primary importance. In the case where national unity in the country is absent, an altogether different political outcome occurs instead of democracy - polarization results in disintegration and regional, ethnic or any other division.

For the continuous stability and legitimacy of established democratic regime, consolidation is of utmost importance, i.e. adaptation of society to a new approach to conflict regulation. A characteristic feature of transition from democracy stage to consolidation stage is a broad participation of the population in election. The entire society accepts democracy as the only possible way of further development and rejects any possibility of forming other regimes. Amorphous condition of social structure creates obstacles in the way of democratization; one of those is the impossibility of forming multi-party representation of social interests in relatively short time, without which governance of the country remains influenced by other, much less controlled forces, threatening social stability.

The balance between authoritarian and democratic elements of social organization during transition period is one of the most controversial issues. These two forms of political domination are more interconnected than they seem at first sight. Thus, authoritarian elites often use democratic techniques for strengthening their domination. At the same time, certain authoritarian factors are able to accelerate institutional and administrative arrangements of democratic governments, serving in fact as their safeguard. In order to determine the impact of civil society on the establishment of democratic political regime and democratic 
orientation of political culture, it is necessary to single out the basic characteristics of the concept. Without going too deep into analysis of approaches to the notion civil society, it can be defined as a system of autonomous and non-statedependent interpersonal, family, economic, cultural, religious, political relations and structures, aimed at providing the conditions for the realization of personal and communal potential. There is a direct correlation between a developed civil society and active state. Priorities of civil society are expressed at the turning points of political process - at the elections, while forming state authorities, when the perspectives of change depend on the society, renewal of state authority, and improvement of the administrative effectiveness of its structures.

Studying political behaviour patterns of power in the process of development and consolidation of democracy is a vital issue. The so-called subjective approach, which conceives democracy as a kind of understanding between different social groups who decided to find a way out of crisis, is becoming widespread. The importance of investigating political culture is also due to influence of different social groups on the political institutions and, respectively, on the character of political regime; political culture has a direct impact on the form and efficacy of political system. In almost every place where democracy process is emerging, organization and mobilization of groups according to interests takes place. This phenomenon could be defined as a revival of civil society. This is a reason why an overview of the processes occurring in civil society during the development of democracy is necessary for the understanding of transformation of political culture.

The subject of political culture is an integral part of literature on radical political transformations that swept across most parts of Europe. In each of these countries, development of democratic political culture followed its own way depending on historically formed national conditions and international circumstances, but certain common features may also be observed. Therefore, when identifying patterns of transition from non-democratic orientation of political culture to a democratic one, it is of the utmost interest to compare the different options and specific situations occurring during the formation of democratic political culture within evolutionary processes of social democratization.

Political culture is characterized by its strong connection to human subjectivity and is regarded as a "subjective object". In a narrow sense, political culture represents neither policy, nor political process in its implementation, but a complex of ideas of a certain national or sociopolitical community with respect to the world of politics, laws and regulations which govern its functioning. Political culture contains those elements and phenomena of social 
consciousness and, to a broad extent, the intellectual culture of a certain country that are related to sociopolitical institutions and political processes and influence forms, formation, functioning and development of state and political institutions, determine the value and guidelines of political process in general, and state administration in particular.

Globalization involves acceleration of national integration into the global system through the development of modern vehicles and economic relations, as well as impact of the media on the people. It promotes expansion of cultural contacts between nations and human migration, but globalization definitely has its pros and cons, therefore, the objective of government agencies is to coordinate the influence of globalization factors on the sociopolitical culture. The negative aspects include potential loss of cultural identity, which takes place as a result of acculturation and assimilation. The primary threat, arising together with globalization, consists in unification of various community attitudes, although during unification the greatest advances of civilization are likely to cease their existence.

Global culture standards, in whole or in part, are not viable given the perspective of national identity. Political culture develops guidelines for political behaviour, social rules and ideals, making administrative sphere both complete and integral. In the same way, national culture makes social life complete and integral. Political culture acts as an ultimate explanatory principle and a key indicator for developing a political system ${ }^{1}$. When theorists have moved from conceptualization and substantiation of methods to their empirical verification, it was found that each model offers both benefits and significant pitfalls that put even certain key points in question. Thus, first of all, it is necessary to define the object and subject of political culture. While studying political culture, we should not discount its specificity and difference from basic characteristics of political culture of other social groups. Sometimes, it may appear completely dissimilar, therefore it should be regarded as a separate category. Political consciousness, as the most essential structural component of political culture and political culture itself have their own classifications ${ }^{2}$. Understanding of the object of political culture proves equally important for the understanding of that

${ }^{1}$ Opozytsiya v Ukraini. Analitychna dopovid. Tsentr Razumkova, [in:] Zapovit, Kiyv 2002, pp. 38-81.

${ }^{2}$ M. Logunova, M. Piren, V. Rebkalo. Politychna psykhologiya, [in:] UADU, Kiyv 2002, p. 64 . 
culture as such. This object, being under the influence of subjective guidelines, values and personal beliefs, represents the whole political system in general and its individual components in particular: the political regime, state, political institutions and parties.

Political culture is a system of relations and, simultaneously, the process of formation and reproduction of its constituents by generations changes them in turn. This dynamic phenomenon, the content and form of which is constantly enriched with history, readily responds to changes in the real life, either industrial, scientific-technological, computer, information revolution or any other watershed event. The concept of political culture appears very attractive due to the polysemy and diversity of dimensions ${ }^{3}$. On the one hand, it is the result of human personal experience; on the other, it reflects history of the political system whose roots date back to the ancient public events. Politicaladministrative approach enables to overcome legalistic perception of politics and step outside the bounds of regulatory description of political processes. The traditional approach to politics employing terms such as "political system" and "political ideology" in the research of legal institutions cannot explain why socio-political bodies, though identical in shape, function differently in various countries and why the same institutions appear viable in certain countries and completely unacceptable in others ${ }^{4}$. Political-cultural approach offers an opportunity to capture social realities, overcome the traditional, superficial and one-dimensional vision of political system, its institutions, their activities, etc., and to educe deeply hidden roots of national myths, traditions, conceptions, etc. that exist in the consciousness of all members of a society. It is possible to settle these issues in a proper way when political culture is not considered the main factor that determines political competition and conflicts, but as a mediating link between socioeconomic interests, administrative structures, social status, moral and ethical values of a certain person, social groups, and classes involved in politics on the one hand, and their political behaviour on the other ${ }^{5}$.

Political culture contains components, political traditions, formed during many generations, political norms, ideas, conceptions and beliefs, concerning

${ }^{3}$ F. Rudych. Politicheskaya situatcyya v Ukraine na kanune prezydentskykh vyborov, [in:] Sotsyalno-gumanitarnyye znaniya, Kiyv 1999, pp. 24-36.

${ }^{4}$ Gromadiany Ukrainy pro vnutrishniopolitychni procesy, [in:] Natsionalna bezpeka i oborona, Kiyv 2003, pp. 9-30.

${ }^{5}$ O. Shakhtemirova, Zasoby masovoyi informatsiyi ta politychni oriyentatsiyi gromadian Ukrainy, [in:] Nova polityka, Kiyv 1999, pp. 10-14. 
relationships of different sociopolitical institutions. It includes human orientations and attitudes in relation to the existing social system as a whole, components of its institutions and ground rules for "the game", as well as principles of individual, social and state relationships. These components, engendered by socioeconomic, ethno-cultural, socio-historical and other long-run factors are characterized by relative constancy, duration and slow changes compared to profound transformations in social life $\mathrm{f}^{6}$. Understanding of political culture as a characteristic of developed social subject, level of realization of its basic forces in the field of political relationships that occurs in mastering political regulations, gaining political experience and in the level of political consciousness becomes supremely important.

It is necessary to pay particular attention to the fact that the type of management performed by authoritative institutions in the sphere of politics, ideology and culture, plays a special role when determining functions of information transfer. The main idea behind this activity is exercising influence on the human consciousness in which desirable properties and qualities are formed, approaching the ideal that suits political, cultural and ideological forms and values of society ${ }^{7}$. The direction of functions is defined by the place of the subject whose political culture is studied in the system of social relations.

The general pattern of manifesting functions of political culture in a translation process consists in defining political culture of society by the function of instructions and political culture of social group by the function of perceptions. Political culture has a dynamic multifunctional nature and combines all historically formed social properties in the sphere of politics, permanently forming new ones concurring with the development of the nature of social relations. In this sense, it becomes obvious that political culture cannot be changed solely under the influence of transforming public administration, but also vice versa - it can have an impact on this system. The concept of political culture has recently become of particular importance with the intensification of globalization processes, resulting in a blurring of the boundaries between national states, rapid information flow and dissemination of certain universal ideals and values ${ }^{8}$. These

${ }^{6}$ M. Golovaty, Problemy i bil stanovlennia ukrainskoyi elity, [in:] Nova polityka, Kiyv 1999, pp. $45-49$.

${ }^{7}$ Parlamentv Ukraini: tendentsiyi ta problemy stanovlennia, [in:] Natsionalna bezpeka i oborona, Kiyv 2003, p. 28.

${ }^{8}$ M. Logunova. Politychna kultura - vplyvovyy instrument formuvannia gromadianskogo suspilstva v Ukraini, Kiyv 2001, pp. 323-327. 
ideals serve to form the corresponding political culture that spreads all over the world and becomes the basis for the formation of democratic social institutions in different countries.

The main feature of the crisis of democratic process is total alienation of society from conceptual power. The point is that the problem of a thoroughly democratic regime does not consist in in the voting methods or other attributes of formal democracy, but in constructing a social public order where everybody has free access to achieving the fullness of knowledge, i.e. to the top of conceptual power, which is the starting and ending point of all outlines of management in a society; it is quite difficult to accomplish at the level of global governance ${ }^{9}$. Transformation of political system should take place "at the bottom" - from citizens to the state as the administrative machinery; obviously, such changes require certain time ${ }^{10}$. However, taking into account the rapid development and improvement of mass media we may say that the period of time needed for irreversible changes in the political culture of population and the corresponding transformation of the nature of political system will be directly proportional to the rate of development of international communications.

Political culture is a multi-level and multi-functional phenomenon, containing plenty of structural components. Thus, this phenomenon may vary depending on its studying on the following levels: level of a single individual, level of a group of individuals, level of political community and level of society itself. Moreover, depending on the level this many-sided phenomenon will include different elements in different correlations and degrees of their importance ${ }^{11}$. Political values and process, recognition of the human value as a core one in the society, as well as the nation as a source of power and state sovereignty are extremely important elements for the social level. Political culture is not a material sphere and it is not limited definitely to the intellectual or cultural values. This is a particular type of culture, which characterizes the level of social development, classes and personality as subjects for the formation of social relations. Political culture manifests itself in the real life through the political structure of society and the level of development of political processes. At the same time it

\footnotetext{
${ }^{9}$ Ukrainske suspilstvo: desyat rokiv nezalezhnosti: Sotsiologichnyy monitoryng ta komentar naukovtsiv, Kiyv 2001, p. 662.

${ }^{10}$ A. Chichanovskyj, Novyna vzhurnalistytsi: problemy praktychnoyi polityky, [in:] Gramota, Kiyv 2003, p. 48.

${ }^{11}$ O. Levchenko, Masova politychna svidomist perekhidnoyi doby: ukrainski realiyi ta perspektyvy, [in:] Nova polityka, Kiyv 1999, pp. 20-22.
} 
is also reflected in specific aspects in all other forms of culture: it sets the social orientation of economic development in material production, affects economic priorities of one or another class; in the legal sphere it is expressed by the level of development of legislative system, protection of different social groups by law; in arts and literature it can be defined by the level of their disclosure of national values, patriotic motives and social justice ${ }^{12}$.

Political process is regarded to be the main way in which political culture is realized. The specific character of their interaction consists in the fact that, on the one hand, political culture is expressed through political process and becomes comprehensible for people, but on the other, political process itself forms political culture. Political process is a complex activity, in particular, of governance institutions, during which the formation, modification, transformation and functioning of the political system in a society occurs ${ }^{13}$. Its structure is a series of successive interconnected stages, evolving cyclically. This is institutionalization, formation of political system, acceptance and implementation of political and administrative decisions; control over the functioning and developmental directions of political system. Globalization in the cultural sphere resembles diffusion. Spontaneous and non-controlled borrowing of cultural properties has both positive and negative aspects. On the one hand, it enables nations to interact and to know each other. Furthermore, communication and knowledge contributes to the rapprochement between the nations. On the other side, excessively active communication and borrowing poses the threat of losing cultural identity. The spread of the same cultural patterns all over the world, openness of borders for cultural influence and expanding cultural communication forced scientists to address globalization process of modern culture ${ }^{14}$.

Global changes have already resulted in numerous management problems, requiring fundamental revision at the present time. It concerns the problems of human rights, cultural pluralism and solidarity. In the changed socioeconomic and cultural environment, given its unpredictable nature, it is necessary to find adequate political decisions. The most common cause of a political standstill in the government consists in the strong pressure to support improvident ac-

\footnotetext{
${ }^{12}$ V. Bucevycky, Problemy politychnoyi kultury v Ukraini v protsesi derzhavotvorennia, [in:] Nova polityka, Kiyv 1999, pp. 48-51.

${ }^{13}$ Politychna tsenzura v Ukraini. Analitychna dopovid. Tsentr Razumkova, [in:] Zapovit, Kiyv 2003, pp. 82-111.

${ }^{14}$ A. Dzhenusov. Razlichie struktur i urovnieyrazvitiya politicheskoy kultury, [in:] Sotsyalnogumanitarnyye znaniya, Kiyv 1999, pp. 108-121.
} 
tions, which may have serious long-term consequences. Such situation is likely to occur even in modern democratic societies. Particular importance should be attached to adoption of external ideas and institutions to the local political culture that is called globalization ${ }^{15}$. Taking this fact into consideration, the formation of political culture becomes the only possible challenge for institutions of public administration. Only with the help of universal guidelines will the necessary level of mutual understanding be achieved. The general elements of political culture must be developed everywhere in order to form the basis for global governance and promotion of human interests in the constantly integrating world.

Political culture is a dynamic and diversified function of society, combining all historically formed social properties in the sphere of politics, both material and ideological. Just as political culture of society can be influenced by transformations of political system, so the political system may transform as a result of changes in the nature of state administration. The property of political culture becomes greatly significant in the conditions of scientific and technological progress and strengthening of globalization processes. Due to advancements in mass media, it increasingly blurs the boundaries and spreads universal politicalcultural patterns and values all over the world. In turn, those values influence the formation of a new type of civic political culture of certain national states, eventually transforming their political systems. Hence, there is a direct relationship between the dynamics of globalization, governance institutions and democratization processes. The period of time, required for changes in political culture and corresponding transformations of political system, will be directly proportional to the rates of development of international communications.

The impact of globalization on culture and vice versa is a dialectical process. Globalization promotes integration and not only removes cultural barriers but also many negative cultural dimensions. Globalization is a vitally important step towards a more stable world and better life for people in the world. Reduction of cultural differences may become a criterion of civilizational progress and a tangible step with respect to the role of institutions holding authority in coordinating the influence of globalization factors towards consolidation of international relations and mutual understanding. The information age is an opportunity to remove the barriers that separate nations and ethnic groups

${ }^{15}$ N. Panina, E. Golovakha, Tendenciyi rozvytku ukrainskogo suspilstva. Sociologichni pokaznyky, Kiyv 1999, p. 152. 
within the nations and to build relationships that will provide much greater potential for common interests among much greater community of nations. Cultural globalization is a dialectical process, where globalization and localization, centralization and decentralization are not mutually exclusive antipodes, but vice versa, two sides of the same coin. As a result of increasing interconnections, old forms of diversity disappear and at the same time a new cultural diversity emerges. Intelligibility of many different worldviews and lifestyles promotes fruitful dialogue and gives a great opportunity for self-realization and social enrichment.

Establishment of democratic political culture is a transition from monoideology of totalitarian society to ideological and political pluralism. In democratic societies, there is a dialogue of political ideologies. The positive role of the dialogue lies in the fact that thanks to it none of the essential values will be forgotten or depreciated ${ }^{16}$. Political pluralism is a basic line for democratic political culture, meaning recognition in the political life of diverse interests, values of different interdependent and at the same time autonomous social and political groups, parties, organizations, expressing their right and ability to have their own point of view on a particular issue, variety of attitudes and ideas and their reflection in the governance system, functioning of all its institutions, alternativeness in administrative decision-making.

Political culture permeates the entire set of relations, appearing between members of political process, influences forms and government institutions, the structure of its institutions, allows effective regulation of relationships between state and civil society, provides a social consensus. Political culture is the factor that may directly promote or prevent democratic political development. This fact may be also proved by practical experience of developed democratic states, showing that democratic political culture itself is a foundation of their stability and dynamic functioning ${ }^{17}$. Understanding of political regime as a functional characteristic of political system, including methods and ways of political governance, as well as the relations between citizens, society and political authority, enables one to define the relationships between political culture and regime, together with its place in the regime.

Conversion to democracy represents a complex of several developmental stages, but it does not encompass all political transitions. In each instance,

\footnotetext{
${ }^{16}$ V. Bucevycky, Problemy, pp. 48-51.

${ }^{17}$ M. Logunova, M. Piren, V. Rebkalo. Politychna, p. 64.
} 
the challenges of liberalization and democratization, realization of political and administrative reforms were handled in a different way, order and term. Liberalization can either cause ongoing changes, or provoke repressions and thereby strengthen authoritarian regime; changes are more likely to happen when transformation occurs from the top ${ }^{18}$. Vigorous actions from the bottom most often provoke strengthening of the regime and escalating confrontation that may result in revolutionary downfall of a political system; when changes do proceed, the stage of democratization comes. In essence, further development of transitional process does not depend on the initiative from above, as it was during liberalization, but also on a consent between new participants of political compromise, involved from below. At the stage of democratization, one observes a qualitative change of the political system: formation of the democratic political institutions and structures that interact on the basis of democratic procedures.

Democratization is a complex, diverse process, occurring in several simultaneous directions. The most characteristic feature of transformation is simultaneous establishment of liberal democracy and change of governance system. When transformation of political institutions and structures becomes a subject of research, political culture, as essential element of whole democratization process and key factor at the consolidation stage receives much less attention ${ }^{19}$. This confirms the need for detailed study of the democratic transformation of political culture. Transformation of political culture occurs in several directions and includes transformation of political consciousness and mass behaviour, as well as transformation of the culture of activity of political institutions. Transition from a non-democratic political culture to a democratic one is accompanied by the transition from mono-ideology to ideological pluralism, a kind of administrative sphere in developed countries ${ }^{20}$.

In a normal state of society, we are dealing with a consensual political structure, with a high level of harmony and most members of society having a positive attitude to its political institutions. Such kind of political culture is based on centrist ideological orientations. In the conditions of polarized political culture, a significant part of society is divided according to the perception of

${ }^{18}$ F. Rudych, Politicheskaya, pp. 24-36.

${ }^{19}$ N. Panina, E. Golovakha, Tendenciyi, p. 152.

${ }^{20}$ I. Pasko, A. Pasko. Gromadanske suspilstvo i natsionalna ideya: Ukraina na tli yevropeyskykh protsesiv, [in:] Skhidnyy vydavnychyy dim, Donetsk 1999, p. 184. 
political norms and ideals. In this case, ideological orientations move away from the centre, acquiring distinct right or left orientation. Transition from non-democratic political culture to democratic one is the transition to autonomous participation, established on the possibility of choice and is specific to developed civil society and competition in politics. Leaders and parties seek support from citizens since their choice directly influences formation of the government. Developed democratic states are characterized by low political activity of population that, as a rule, is limited to participation in elections and institutions of civil society. Non-participation of citizens in political life in developed democratic countries can be also explained by the confidence of citizens in administrative subjects, satisfaction with their situation and stability of state power.

Citizen involvement in elections is promoted by the presence of developed democratic political culture, allowing free expression of the will of the nation that has the right to choose the country's leaders in the conditions of political pluralism and democratic choice. Active participation is caused by strong support of political regime by citizens on the whole and confidence in its ability to influence the government. Democratic political culture is the culture of civil society ${ }^{21}$. It is within the civil society that the organisation of pluralism takes place, i.e. combining and taking into account the interests of various social and political forces. Only in a developed civil society may a culture be formed which corresponds to democratic management style. Pluralism of political actions means the right of citizens to associate in social organisations, provides free and equal activity of political parties and public organisations within the framework of multi-party political system, has an influence on the activity of government and administrative bodies through the legal model existing in the society. The basic principles of democratic political culture include national sovereignty, majority rule, representation, and pluralism.

Civil society is a favourable public environment for formation and spread of democratic political culture and, with its help, for the strengthening of democratic system, providing the democratisation process with irreversible character. Within civil society, organisation of pluralism takes place, i.e. combining and taking into account the interests of various social and political forces; a consensus-based type of political culture is formed as well ${ }^{22}$. Civil society is

\footnotetext{
${ }^{21}$ M.Golovaty, Problemy, pp. 45-49.

${ }^{22}$ Politychna tsenzura, p. 82-111.
} 
also an environment of public socialization, in which people assimilate and support models and standards of behaviour and activity, norms, cultural values and orientations that take into account the existence of society as a whole and there is also a recognized democratic process. Very rarely the change of political regime happens due to efforts of the members of society, but certainly, in further democratization process the level of development of civil society plays an important role, while the stability of democracy depends to a large degree on the extent to which social needs are reflected and on the prompt response of political institutions to occurring processes ${ }^{23}$.

Civil society provides such opportunities of self-expression and identification which are crucial to citizen. In democratic conditions, institutions of civil society serve as a secondary, alternative channel for expression of interests and ideas. This expression of interest leads to an increase of political perception and community potential, political leaders are formed and prepared for participation in mainstream politics and individual desire for democracy is stimulated ${ }^{24}$. Individual and collective interests are also harmonized in civil society. Thus, civil society is an environment of public socialization, in which people assimilate and support models and standards of behaviour and activity, norms, cultural values and orientations that take into account existence of society on the whole, and there is recognized a democratic process.

Civil society means a balanced mutual control and mutual restriction of state and non-state bodies and movements. This means that public authorities and their activities should always be within sight of non-state bodies and movements, and the latter, in their turn, should act in accordance with law, take into account objective needs of the state ${ }^{25}$. It is within civil society that the organisation of pluralism takes place, i.e. combining and taking into account the interests of various social forces that involves their clashes, controversies and conflicts. Civil society is intended to define norms and limits that are able to block the destructive potency against various forces to direct it in a creative course. This is the main purpose of civil society - to achieve consensus between different social forces and interests, fostering consolidation of different public forces on the basis of new values. And only in this way, rather than by means of enforcement, is it possible to achieve real democratic consolidation of society, its development within the limits of new

\footnotetext{
${ }^{23}$ Gromadiany Ukrainy, pp. 9-30.

${ }^{24}$ O. Levchenko, Masova politychna, p. 20-22.

${ }^{25}$ O. Grycenko, V. Shkliar, Presa i polityka: problemy, kontseptsiyi, dosvid, Kiyv 2000, p. 71.
} 
basic values. This is the only way a new regime may be supported by a majority, the permanent maintenance of which forms the basis for democratic system. However, public support for the government does not exclude the existence of differences and the possibility of constructive opposition.

Public opinion is a historically conditioned dynamic state of mass consciousness of large groups of people, whose content reflects the correlation of social forces actually acting in a society. As an element of functioning of political systems, public opinion is a constant factor of management, by means of which a few powerful functions are performed. Developed democratic countries pay particular attention to obtaining trustworthy information about people's thoughts and attitudes, their responses to certain political events. Public opinion is crucial in the process of making political decisions that significantly affect the interests of major population groups. The competence of public opinion should not be exaggerated in any case and even less absolutized ${ }^{26}$. The talent and competence of a politician consists largely in his/her skills to go ahead of the established tendencies of state and society development, reflected in the stereotypes of mass consciousness, as well as to suggest new ways of resolving political problems. Knowing public opinion it is possible to correct decisions which are being made, anticipate and mitigate adverse effects.

In a democratic society, trust in the authorities is directly defined by its ability to provoke a real dialogue, including public opinion and public society as its main source $^{27}$. Forming a democratic culture at the level of authoritative institutions evolution starts with establishing pluralism of political actions, political power. A great emphasis should be put on defining the structure of pluralism of political power. It suggests multiplicity of political parties and freedoms that characterise it, as well as the main differences between types of authority: autonomy of legislative power, independence of executive and judicial power, legal initiative and independence. It also includes local authorities, mainly public authority that in fact allows to connect huge reserves of independence and initiative; local authority is inextricably connected with the idea of decentralisation ${ }^{28}$. It allows to release higher elements of power from their non-specific operative functions, eliminates over-centralisation of powers and alienation of nation. Thus the process of

${ }^{26}$ Opozytsiya v Ukraini. Analitychna dopovid. Tsentr Razumkova, [in:] Zapovit, Kiyv 2002, pp. 38-81.

${ }^{27}$ S. Chukut, Chogo ne vystachaye pravlyachiy eliti v Ukraini, [in:] Viche, Kiyv 1999, pp. 39-47.

${ }^{28}$ Ukrainske suspilstvo, p. 662. 
implementing power and decision-making is based upon pluralism of interests and solidarity of purpose shared by most community groups. It means that the dominant method in decision-making is a compromise as the reflection of reconciled interests.

The basic principles of democratic political culture include national sovereignty, majority rule, representation, pluralism form a basis for parliamentarism. Parliamentarism is a political institution aimed at recognizing necessary competition of political forces ${ }^{29}$. Rivalry and contentiousness, certainly, the clever ones that are not beyond the generally accepted rules of the game, serve as means for stimulation of innovating political activeness of those forces, selection of optimal political decisions. In order to function, democratic political systems need a certain type of political culture. The lack of long-term and large-scale practice with regard to the functioning of democratic institutions prevents consolidation and development of democratic political culture in a society. The main directions of transformation of political culture include forming a democratic type of political consciousness and political behaviour on democratic principles, as well as consolidating democratic culture in the functioning of an administrative institution. At the stage of consolidation of democracy, when introduction of new institutions and new procedures of functioning of social organism become the practice of everyday life, the value of the masses grows. The fate of this stage of transformation is directly dependent on peculiarities of their attitude and consciousness. Establishment of political democracy, and achievement of the required stability by its institutions is possible only when a greater part of the society is involved in appreciating democratic values, i.e. people's awareness of democracy as the most perfect form of state system in comparison with others.

\section{Orest Krasiwski, Ivan Parubchak \\ TRANSFORMACJE KULTURY POLITYCZNEJ W PROCESIE SPOŁECZNEJ DEMOKRATYZACJI PAŃSTW W FAZIE PRZEJŚCIOWEJ}

\section{Streszczenie}

Niedostateczny rozwój instytucji społecznych, słabość partii politycznych i ich niezdolność do wywierania wpływu na decyzje podejmowane na szczeblu

\footnotetext{
${ }^{29}$ Politychna tsenzura, pp. 82-111.
} 
państwowym, państwowa kontrola mediów i ograniczona wolność słowa utrudniają kształtowanie się demokratycznej kultury politycznej na Ukrainie. A jednak w ostatnich latach transformacji znaczna część społeczeństwa ukraińskiego dostrzegła te demokratyczne ideały; wszystkie strukturalne elementy takiej kultury politycznej, tzn. wartości, umiejętności, kierunki, metody i techniki działań politycznych, uległy zdecydowanemu unowocześnieniu. Stopniowo społeczeństwo przyzwyczaja się do politycznego pluralizmu, znacznego zróżnicowania podejścia do rozmaitych kwestii czy otwartego wyrażania idei. Kultura demokratyczna rozwija się nadal w ramach ewolucyjnych procesów charakterystycznych dla społeczeństw w stadium przejściowym. Perspektywy dalszego ich rozwoju obejmują zmiany w obrębie ustroju administracyjnego, utrwalenie demokratycznych form rządzenia, powstanie społeczeństwa obywatelskiego i zagwarantowanie nadrzędnego znaczenia praw człowieka i swobód obywatelskich.

\section{Bibliografia}

Bucevycky V., Problemy politychnoyi kultury v Ukraini v protsesi derzhavotvorennia, [in:] Nova polityka, Kijow 1999.

Chichanovskyj A., Novyna vzhurnalistytsi: problemy praktychnoyi polityky, [in:] Gramota, Kijow 2003.

Chukut S., Chogo ne vystachaye pravlyachiy eliti v Ukraini, [in:] Viche, Kijow 1999.

Dzhenusov A., Razlichie struktur i urovnieyrazvitiya politicheskoy kultury, [in:] Sotsyalno-gumanitarnyye znaniya, Kijow 1999.

Golovaty M., Problemy i bil stanovlennia ukrainskoyi elity, [in:] Nova polityka, Kijow 1999.

Gromadiany Ukrainy pro vnutrishniopolitychni procesy, [in:] Natsionalna bezpeka i oborona, Kijow 2003.

Grycenko O., Shkliar V., Presa i polityka: problemy, kontseptsiyi, dosvid, Kijow 2000.

Levchenko O., Masova politychna svidomist perekhidnoyi doby: ukrainski realiyi ta perspektyvy, [in:] Nova polityka, Kijow 1999.

Logunova M., Politychna kultura - vplyvovyy instrument formuvannia gromadianskogo suspilstva v Ukraini, Kijow 2001.

Logunova M., Piren M., Rebkalo V., Politychna psykhologiya, [in:] UADU, Kijow 2002.

Naumkina S., Kozlovski L., Analiz rozvytku ukrainskoji politychnoyi elity, [in:] Nova polityka, Kijow 1999.

Opozytsiya v Ukraini. Analitychna dopovid. Tsentr Razumkova, [in:] Zapovit, Kijow 2002. 
Panina N., Golovakha E., Tendenciyi rozvytku ukrainskogo suspilstva. Sociologichni pokaznyky, Kijow 1999.

Parlamentv Ukraini: tendentsiy ta problemy stanovlennia, [in:] Natsionalna bezpeka i oborona, Kijow 2003.

Pasko I., Pasko A., Gromadanske suspilstvo i natsionalna ideya: Ukraina na tli yevropeyskykh protsesiv, [in:] Skhidnyy vydavnychyy dim, Donetsk 1999.

Politychna tsenzura v Ukraini. Analitychna dopovid. Tsentr Razumkova, [in:] Zapovit, Kijow 2003.

Rudych F. Politicheskaya situatcyya v Ukraine na kanune prezydentskykh vyborov, [in:] Sotsyalno-gumanitarnyye znaniya, Kijow 1999.

Shakhtemirova O., Zasoby masovoyi informatsiyi ta politychni oriyentatsiyi gromadian Ukrainy, [in:] Nova polityka, Kijow 1999.

Summbatian U., Politologiya. Avtoritarizm kak kategoriya politicheskoy nauki, [in:] Socialno-gumanitarnyye znaniya, Kijow 1999.

Ukrainske suspilstvo: desyat rokiv nezalezhnosti: Sotsiologichnyy monitoryng ta komentar naukovtsiv, Kijow 2001.

Zhuravsky V., Politychna systema Ukrainy: osoblyvosti, factory, chynnyky prava, [in:] Viche, Kijow 2000. 
